\title{
Memory, evidence, and artifice: the overseas journal in New Zealand post-war architectural historiography
}

Michael Dudding, School of Architecture, Victoria University

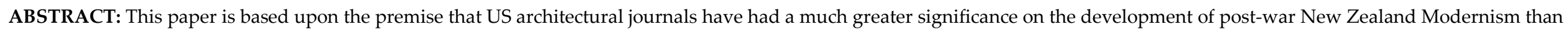

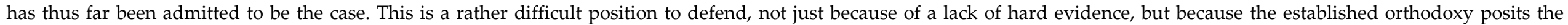
English Architectural Review as the "bible" to this generation of architects.

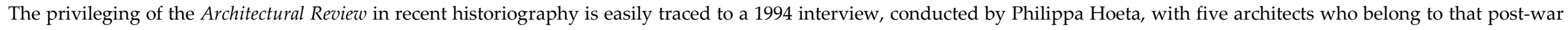

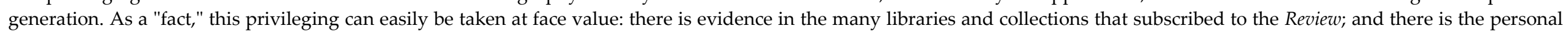


other truths are overlooked, skirted around, rejected, or forgotten - perhaps there was more than one gospel?

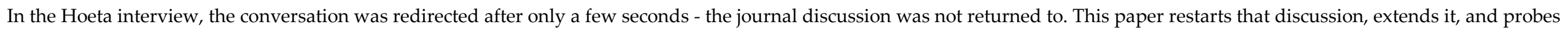
deeper to find the role and significance of the other journals that sat next to the Review on local architects' shelves.

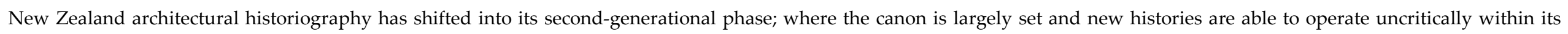


process from which it arose, and investigates what has been obscured by uncritical adherence to its complete veracity.

\section{Introduction}

"The Review," states Bill Toomath, "...was the Gospel."1

Toomath's response was echoed by the four other postwar New Zealand architects taking part in the 1994 interview. Ostensibly dealing with the modes of transmission by which the influence of Modern architecture arrived in New Zealand, the total discussion of this particular topic, part of a 1994 interview conducted by Philippa Hoeta, lasts only two

1 Alington, Beard, Porter, Toomath, Treadwell, 15 December 1994. minutes. Nevertheless, its impact on the narratives of postwar architectural history in New Zealand has been of a much more widespread nature than might be expected from a recording as short as 120 or so seconds: in referring to the significance of the English journal, The Architectural Review (AR), in such emphatic terms, Toomath (and his cointerviewees) locate $A R$ as the primary vehicle of dissemination for mid-century Modernism in New Zealand.

Hoeta's interview was part of a larger research project that examined the Architectural
Centre's role in the development of postwar New Zealand architecture. Two of its instigators, Julia Gatley and Paul Walker went on to use the material that Hoeta gained in influential texts. It is in their writings that the "biblical" status of $A R$, implied by Toomath's words, is repeated: Gatley's "For Modern Living," published in the 1996 book Zeal and Crusade; ${ }^{2}$ and more significantly in the 1995 Interstices article "Privacy and Propaganda;"3 and Paul Walker, along with Justine Clark, in

\footnotetext{
${ }^{2}$ Gatley "For modern living" p 54.

${ }^{3}$ Gatley "Privacy and propaganda" p 7.
} 
their book Looking for the Local. ${ }^{4}$ That is not to say that other writers had not refered to the $A R$ as a key source of Modernist ideals for mid-century New Zealand architects prior to the Hoeta interview - Michael Findlay, for example, claimed that "New Zealand modernism was largely founded on the images projected through the English journals," including $A R,{ }^{5}$ while Peter Shaw's seminal survey refers to both $A R$ and the US journal Pencil Points $(P P)$ as being instrumental in raising the awareness of overseas modern developments in the minds of New Zealand students in the first half of the twentieth century. ${ }^{6}$

\section{Returning to the conversation}

It is a simple enough statement, and one which, by most accounts, can be accepted at face value. But what happens when if you don't take such a statement to be as axiomatic as it at first appears? I sought out the original Hoeta recording, initially to see whether the conversation discussed the influence of $A R$ in greater detail, and to see whether other sources were mentioned. What I found was more than a little perplexing ...

4 Clark \& Walker Looking for the Local p 17.

${ }^{5}$ Findlay "Barbarians at the Gate" p 146.

${ }^{6}$ Shaw A History of New Zealand Architecture p 102.
Philipa Hoeta: Where did the Modern Movement, the International Style influence come from - was it from people travelling overseas in the war years and seeing those places...?

All: Journals

George Porter(?): Journals mainly. Journals were read avidly weren't they?

$(?)$

Yes

GP: $\quad$ Particularly

Bill Toomath: Particularly the Review - that was the Gospel.

PH: $\quad$ Any other...?

BT: None of us realized how strongly propagandist it was. I think we all took it as being the Gospel. It's only in later years you look back on it and you realise that Richards and Pevsner, they had a very definite political view, and they were using the Architectural Review to push it. Not that I'm saying that's an altogether bad thing at all. But, in many ways they were innocent days - you didn't realise you were being manipulated by journals...

(?): [indistinguishable + laughing]

BT: Well we know we're being manipulated today. Those earlier days you didn't really suspect it.

GP: John Cox and Plischke, I suppose were the mentors weren't they?

$$
\text { ... }
$$

Here is a topic of conversation that is cut off just a little after it had begun, eliminating any opportunity to probe further - and nor is it returned to later in the interview. Toomath is interrupted, almost mid-sentence, just as he is launching into a discussion of the nature of the $A R^{\prime}$ s influence, and well before the question is broadened to include other journals, or indeed if one returns to the actual question posed, other modes of dissemination. Thus, as a piece of evidence, the interview excerpt is incomplete, and consequently, any citation relying on this particular excerpt can only tell a part of that story.

There is little to be gleaned from the two minutes of conversation from the Hoeta interview, beyond the fact that $A R$ was of obvious significance to the group of interview subjects: Hoeta demonstrates a degree of indeterminacy in her use of historical labels, while Toomath reveals a more sophisticated awareness, in hindsight, of aspects of the $A R$ editorial agenda. Examining the interview more closely begins to raise questions relating to Hoeta's specific prompting of the AR title what would have happened had she not prompted? That is unanswerable now, and there is a good chance that the result may have been the same, but there remains the possibility that an alternative response might have been offered, which (given what follows 
in this paper) might not have been $A R$.

The other interesting aspect of the conversation, in relation to its reported outcome, is Toomath's use of the term "gospel" - the general definition of which is simply: an unquestionable truth. Clark and Walker's shift in terminology to the word "bible" does not necessarily contradict this, as the informal usage (indicated by the lack of the capital "B") simply points to an authoritative text. However, at a less exacting level of analysis, the conflation of "bible" with the Bible is always going to be difficult to ignore. Here, the implication of a single source of authority, God's word, unnecessarily exaggerates the singularity and thus significance of $A R$. Gatley's phrase, "treated as gospel" is far a more accurate one in this context.

\section{Resuming the conversation}

But this would be a short paper if that was all I had to go on - just as there is insufficient data with which to build a complete argument, there is also too little data to adequately critique its use in subsequent texts. What is needed is a continuation of the arrested conversation begun by Hoeta, and that is precisely what I set out to do. Of the five postwar architects interviewed by Hoeta, George Porter and Tony Treadwell are no longer alive, leaving Toomath, Bill Alington, and James Beard as the surviving interview subjects available to resume the conversation. I approached each subject individually, digital audio recorder at hand, in order to do just this. The first interview was carried out with Jim Beard in December 2007, the second with Bill Alington in January 2008, and the final interview with Bill Toomath a few weeks later in early February. All interviews were recorded, and will be made available for future researchers.

As part of a previous research project I had already recorded an oral history with Alington in 2004, where I had posed a similar question to that posed by Hoeta. Alington listed the key sources for the dissemination of Modernist theory, while he was studying at the School of Architecture in Auckland, as: conversations with other students, the reading of books and journals, discussions on Modern art, and the works of local architects. Of the journal titles that he referred to in that discussion, he mentions (in the following order) the US Architectural Forum (AF) and Architectural Record (ARec.), as well as the British $A R$, which he refers to as the "top-rate one."7 Although the latter accolade supports the Hoeta finding, the mention of the other titles is instructive. Of these titles, the $A F$ had already been mentioned previously in the interview. Alington had described a vacation job that he took at the NZ Railways design office while studying toward an Engineering degree in the late 1940s. Under the encouragement of Railways Architect Ivan Clarkson, Alington was exposed to $A F$, and it was within those pages, and more specifically in the illustrations of contemporary US Modernist houses, that his interest in architecture was "awakened" - Alington describes the feeling at the time as of being "simply blown away." 8

Bill Toomath's first experience with architectural journals was also via $A F$, although occurring in the early 1940s - at the opposite end of the decade than Alington. This is a parallel that would be of much curiosity had it not been that Toomath's "awakening" to Modern architecture occurred slightly earlier than his introduction to $A F$, specifically, via JM Richards' book, An Introduction to Modern Architecture. Toomath

${ }^{7}$ Alington W H Alington oral history project 1.02/1:24:55. ${ }^{8}$ Alington W H Alington oral history project 1.02/0:46:21. 
read Richards as a schoolboy of about 15 , and a short while after that, began reading $A F$ whilst whiling away time at the Wellington Central Library. Although Toomath is unable to recall exactly why $A F$ was the first journal that he began to follow, and he does recall that he began to read $A R$ not too long after - it is tempting to speculate that $A F$ was simply the first series encountered, by virtue of the alphabetical arrangement of the periodical shelves.

Like Alington, Toomath also describes being blown away by this initial exposure to Modernist work. In both of the Toomath and Alington autobiographical narratives, their early exposure to $A F$ is structured as a significant turning point, despite the fact they both acknowledge $A R$ as being the most significant journal in terms of influence on their architectural thinking. For Toomath, $A F$ provided confirmation that the principles of Modernism, as outlined by Richards, were being realized in the built world, while for Alington, the buildings pictured within were his first real experience with the new formal vocabulary of Modernist architecture.

Architectural journals provided no such moment of epiphany for Jim Beard, who instead found himself "guided" into his career as an architect. ${ }^{9}$ He describes being "grabbed" by architecture while already employed as a draughting cadet in the Architectural Division of the New Zealand Ministry of Works (MoW). Nevertheless, like Toomath and Alington, journals did play an important role in helping to shape his architectural education and thinking. He cites, in the following order, the US journals, Architectural Record and Pencil Points (PP), and the English $A R$ and Architects Journal $(A J)$ - again, acknowledging $A R$ as the journal that he read avidly. ${ }^{10}$

The recall sequence of the journal titles is an interesting facet of the discussions that deserves closer attention. Despite the emphatic singularity of $A R$ in the Hoeta interview, and all three subjects of the current study agreeing that it was the most enlightening and stimulating of the architectural journals, in both the Alington and Beard oral history interviews, its title came to mind only after the US journals. This pattern of recollection may or may not be instructive - there is no real way of telling but it is at least worth noting.

${ }^{9}$ Beard J A Beard oral history project 1.01/1:07:23 ${ }^{10}$ Beard J A Beard oral history project 2.01/1:01:30.
While Toomath also discusses $A F$ prior to $A R$, his instance differs in that, rather than an act of free recall, he narrated a carefully prepared version of events in which the titles appeared chronologically rather than through actual recall. This also occurred, although to a less marked degree, when I returned to interview Alington on this topic in 2008, as he, like Toomath, was aware of the focus of that particular interview. While the opportunity for using memory-related strategies for analysing the interview data is dissipated by such prior preparation, it has other, more obvious benefits. In the dedicated journal interviews, both Toomath and Alington were able to recall a much wider range of journal titles than were able to be recalled in the more general Alington and Beard oral histories. The range of journals across all of the interviews included: the US titles - Architectural Forum (Alington 2004 and 2008, Toomath), Architectural Record (Alington 2004 and 2008, Beard, Toomath), and Pencil Points (later Progressive Architecture) (Alington 2008, Beard, Toomath); British titles - and Architects' Journal (Alington 2008, Beard, Toomath), Architectural Review (Alington 2004 and 2008, Beard, Toomath), and AA Files (Alington 2008); Italian titles - Abitare (Toomath), Domus (Alington 2008, Toomath), and Spazio 
(Toomath); French titles - L'Architecture d'Aujourd'hui (Alington 2008, Toomath), and Techniques \& Architecture (Toomath); and the Japanese titles - Shinkenchiku (later Japan Architect) (Alington 2008, Toomath). The only titles mentioned in all four interviews were Architectural Record, and Architectural Review.

The $A R$ was nominated by all three subjects as the crucial journal, being variously described as "the principal" journal in terms of the dissemination of Modernist ideals, ${ }^{11}$ "a revelation in so many ways,"12 and as providing an "intense scholarly view in [its] critiques," which was lacking in other journals. $^{13}$ Thus this aspect of the interpretation of the Hoeta excerpt is largely confirmed by these subsequent interviews. But the singularity of $A R$ as the journal of influence that arises from the Hoeta interview, has not yet been addressed. Although we now know that other titles were available (and to be fair to Clark and Walker, they do list a range of other available titles that were read, before throwing in their lot in with $A R$ ).

Toomath's subscription to various architectural journals provides a good

${ }^{11}$ Alington 23 January 2008 7:44.

${ }^{12}$ Toomath 5 February 2008 1/0:14:38.

${ }^{13}$ Beard J A Beard oral history project 2.01/1:07:30. indication of the titles that were important to him. In 1945, in his first year as an architectural student in Auckland, he took out his first architectural journal subscription with Pencil Points. He describes becoming increasingly attracted to $A R$ as during his early studies, and a year later, to his "great joy," his parents gifted him with that subscription. Further subscriptions were taken up when Toomath entered practice in the 1950s: Architectural Record, Shinkenchiku (later Japan Architect), and L'Architecture d'Aujourd'hui.

Alington and Beard, both under the employ of the MoW (Beard from 1941 and Alington from1949), had access to a wide range of journals at the Head Office where they worked, and therefore had little need to take up personal subscriptions (aside from the fact that Gordon Wilson was notorious for taking the journals out of circulation by taking them home and neglecting to return them to the office $\left.{ }^{14}\right)$. Thus, establishing any sort of hierarchy for the various titles is a little more problematic. While it is easy enough to pose the question, which I did, the responses have to be taken with a grain of salt. I asked both

${ }^{14}$ Alington 2008 17:10.
Alington and Beard to recall the title they most anticipated receiving at their desk, with both predictably responding $A R$. Secondary titles are less certain, with Alington selecting "L'Architecture d'Aujourd'hui or something like that," and Beard a less than emphatic "Architects Journal." The divergence here may indicate the different personalities of the two architects, but given the consistency of their positions on almost everything else concerning this topic, is likely to be symptomatic of a completely different phenomenon - the unreliability of certain types of memory recall.

Understanding how memory works - a heady mix of neurology and psychology - is a huge and complex discipline in its own right, and one that can only be touched upon here. Nevertheless, it is important that the specifics of memory recall are addressed if personal narratives are being evaluated as historical data. In the broadest terms, declarative memory (the type of memory that relates to facts that we can declare), as opposed to procedural memory (which applies to skills and procedures), consists of episodic memories (personal experiences, tied to a particular time and place), and semantic memories (concept-related memories that are 
not connected to any specific context or experience when acquired).

One distinctive feature of episodic memory is the vividness of its recall. Unlike semantic memory recall, which is simply the recall of certain known facts (disassociated from the experiences by which they were attained), recollection of episodic memories involves, what Wheeler, Stuss, and Tulving describe as "remembering by re-experiencing." 15 This is a sensory-perceptual rich "recollective experience" ("the sense of the self in the past"16), and according to Wheeler et al, best described by William James: "[as] like a direct feeling; its object is suffused with a warmth and intimacy to which no object of mere conception ever attains."17

Autobiographical memory, which is what is being drawn upon in personal interviews of the type conducted for this research, is another matter entirely, and the relationship between it and episodic and semantic

15 Wheeler et al "Toward a theory of episodic memory" p 349.

${ }^{16}$ Conway "Sensory-perceptual episodic memory and its context: autobiographical memory" p 1377.

17 Wheeler et al "Toward a theory of episodic memory" p 333. memories are currently much less well understood. In recent research Cognitive Psychologist Martin Conway arrives at the conclusion that autobiographical memory that which represents and locates the experienced self, or the "me" - is goal oriented. He suggests that episodic memories act as evidence of "goal attainment progress;" memories of day-to-day episodes are quickly forgotten unless they are milestones achieved toward a meaningful goal and are thus linked to the more permanent structures of autobiographical knowledge. ${ }^{18}$

This theory is useful if we consider the reading of $A R$ as an important milestone in becoming aware of Modernist architectural theory - a reasonable goal to assume in this situation, and one that should, theoretically, result in recall of the relevant memories through recollective experience. Alington demonstrated episodic memory recall in his recollection of $A R$, but in relation to the "Townscape" drawing techniques of Gordon Cullen rather than the theoretical content that was the acknowledged raison d'être for reading the journal. Beard, although questioned along

${ }^{18}$ Conway "Sensory-perceptual episodic memory and its context: autobiographical memory" p 1375. similar lines, relied upon semantic knowledge throughout the entirety of the interview section that dealt with journals. Toomath's episodic memories were associated primarily with his exposure to $A F$, and were prompted by his preparation prior to the interview (including recourse to his schoolboy diary), rather than by direct recall per se. His recollections of $A R$, while admirably detailed and insightful, betrayed no evidence of actual episodic recall.

That semantic memories dominated the autobiographical remembering for all three of the participants suggests that the significance of $A R$ is known rather than recollectively experienced. In this scenario, it does not follow that $A R$ was not read, or found to have been personally stimulating in doing so, but it does open the possibility that their knowledge of the outright significance of $A R$ might not necessarily have been acquired through meaningful personal experience. While that is a fairly bold statement to make, it is worthwhile to follow the consequent argument. A provocative hypothesis might reconcile the claimed significance of $A R$ with the demonstrated indifference (in terms of the lack of episodic memory recall), by suggesting that it is historiographic processes that have 
seen $A R$ become entrenched, even in the minds of the protagonists, as the most significant postwar architectural journal. While this is a less likely scenario, it cannot be discounted without further research to locate the origin of this particular narrative - Hoeta's prompting of the $A R$ title within the interview is a clear indication that the belief was apparent before the supporting evidence was documented in her 1994 interview. Toomath's statement, "None of us realized how strongly propagandist it $[A R]$ was," also betrays evidence of hindsight in helping to construct the significance of the journal. What might ultimately render such a search fruitless, however, is the fact that much of the historiographic underpinning of this period of New Zealand architectural history was developed in unrecorded forums, and somewhat ironically in terms of this argument, by its very own protagonists.

Less provocative and more likely, however, are alternative reasons for the lack of recorded episodic memories associated with $A R$ in this survey - the most obvious would be the natural long-term memory loss that accompanies ageing, which is more pronounced in episodic than in semantic memory. ${ }^{19}$ The actual interviews are also likely to have been a contributing factor - I placed no particular emphasis in trying to encourage episodic recall (having only recently become aware of the literature on the subject).

\section{Extending the conversation}

Although most of the journals are readily available for analysis of content and the differences in content between the various journals, I rely here on the recollections Alington, Beard, and Toomath, in order to understand not just what was in the journals, but the actual influence that was drawn from each title. The findings are relatively consistent across the three interview participants, and can thus be summarized as follows:

Although minor differences in the specific focuses of the US journals (AF, ARec, and Pencil Points) were noted, they were generally considered to be "very much the same thing," 20 being directly concerned with the image-rich, reportage of contemporary US buildings (comparisons with "glossy"

${ }^{19}$ Hänninen Age-associated memory impairment ${ }^{20}$ Toomath 5 February 2008 2/0:54:33. magazines and Life Magazine were made by Alington and Beard respectively). ${ }^{21}$ Of the important British journals, $A R$ and Architect's Journal (AJ), were sister publications produced by the Architectural Press. This meant that, unlike the US titles, each journal could have a strongly distinctive focus $-A R$ on the intellectual concerns of the architect, and $A J$ on the more practical aspects of architectural practice. The latter was a weekly publication that contained industry news, aspects of construction law, and of particular interest, information sheets of construction details Toomath specifically refers to it as the "workplace" journal. ${ }^{22}$ This left $A R$ free to develop a broader humanities-style approach to architectural (and art) history and theory, as well as robust critical commentary on the contemporary developments of both built architecture and its contemporary theory. ${ }^{23}$

Surprisingly, Toomath's hindsight notwithstanding, there appeared to be a certain vagueness in the responses as to

${ }^{21}$ Alington 2008 0:57, Beard J A Beard oral history project 2.01/01:11:00, Toomath 5 February 2008 2/0:56:18.

22 Alington 2008 9:23, Beard J A Beard oral history project 2.01/01:05:55, Toomath 5 February 2008 2/0:09:00.

${ }^{23}$ Alington 2008 2:00, Beard J A Beard oral history project 2.01/01:07:30, Toomath 5 February 2008 2/0:10:25. 
exactly how the ideals and principles of Modernism were disseminated through $A R$. Both Alington and Toomath catch themselves on the contradiction between the breadth of the purview of $A R$, and its stated propagandist focus, when questioned specifically on the dissemination of Modernist ideals. It is worth quoting the relevant parts of the interview here - first Alington:

I think the Architectural Review was the principle one, yes. It, I think, it probably had a little more attraction to the architects generally, because it did cover some of the earliest things; it gave articles on Victoriana and things like that a little bit, which meant that... Modernism... wasn't being thrust down your throat. ${ }^{24}$

Toomath begins by saying that the $A R$ was the "most vivid and inescapable influence" in relation to the dissemination of Modernist ideals. A short while later he revises this position:

I think the Review had an open-minded, oh help that contradicted what I've been saying before, I think the Review stood on a very strong ground of principle, and that imbued almost everything that they said about Modern architecture - but at the same time they had this terrific ability to engage the mind in other fields, and to stimulate a more universalized view, which is after all

\footnotetext{
${ }^{24}$ Alington 2008 7:44.
}

what architecture depends on. ${ }^{25}$

In 1961 Nikolaus Pevsner, reflecting on his own impact on the development of twentiethcentury architecture, apologized for his role in what he saw as the "return to historicism." He felt that the successful publication of his architectural history writing (and although he is referring to his Pioneers of Modern Design, he might well have included editorial direction of $A R$ during the $1940 \mathrm{~s}$ and $50 \mathrm{~s}$ in his comments), encouraged historical referencing, which was then becoming apparent in recent architectural projects. ${ }^{26}$ His hubris is not unwarranted, but what is important in this discussion is the fact that he saw the effect of the intellectual breadth of this approach to architectural writing as one that degraded the principle message of the functionalist architectural theory that was he was trying to promote. This echoes precisely the contradictions that Alington and Toomath come up against.

So here we have Alington, Toomath, and Pevsner himself, providing some indication that the propagandistic role of $A R$ was not necessarily as clear-cut as it may at first seem

${ }^{25}$ Toomath 5 February 2008 2/0:27:05.

${ }^{26}$ Pevsner "The return of historicism" pp 274-275.
- and it is here that I believe the propaganda of nationalism interferes and distorts the picture. Principally developed and promoted by Pevsner, but with the support and contribution of the $A R$ editors, historical method was used to locate Modernist architectural and urban solutions as being particularly appropriate to the realization of "Englishness" (see Pevsner's Reith Lectures on this point). The exact influence of this line of thinking on New Zealand postwar architecture is a whole other issue, but my point is that, alongside the general intellectual stimulation provided by the articles on art and architectural history, the theoretical significance that would have been more influential, when read in the postwar New Zealand context, might well have been the extensive nationalist rhetoric.

\section{Concluding the conversation - returning to the question}

So far I have only provided inconclusive challenges to the primacy of $A R$, without actually addressing the question posed in Hoeta's interview: how was the influence of Modern architecture disseminated in New Zealand? It is a question that probably cannot be answered in a discussion of journals alone (for example, Alington cites Le Corbusier's 
Oeuvre complete as being one of the most important modes of Modernist architectural dissemination ${ }^{27}$ ). Nevertheless, a broader response to the question does arise out of this discussion, and it is worth returning to the idea of a "workplace" journal (evoked by Toomath to describe the role of $A J$ ) to elaborate on this. Toomath specifically states that he never considered $A R$ as the type of journal that "you had beside you on the drawing-board." He picks up this point later in the interview, explaining that there are two levels at which journals operated - at the level of "sheer interest in architecture as an activity and the world wide development of it," which he associates with $A R$, and the other is keeping informed as to "what is happening the setting of the standards, and raising improvement and clarifying design vocabulary, in terms of your own working day," and it is the US journals that he associates with this level. ${ }^{28} \mathrm{He}$ goes on to say:

In the day to day formulation of solutions to planning problems and issues, the variety of approaches that were actually presented in American magazines was of very great importance really. ${ }^{29}$

\section{${ }^{27}$ Alington 2008 7:05.}

${ }^{28}$ Toomath 5 February 2008 2/0:53:50.

${ }^{29}$ Toomath 5 February 2008 2/0:54:55.
Beard too, echoes this distinction, by contrasting the more "scholarly view" of $A R$ against the insight into US architectural work, which was provided by the US journals, and which, according to Beard, "was always of great interest." 30 The US journals, free of overt rhetoric (although I would argue that, under the influence of Henry Luce, the existence of implicit rhetoric was inevitable), were imagerich, and by the 1940s, focused almost exclusively on recent Modernist work (both in the US, and abroad). They acted as a visual resource (described by Toomath as a "reference collection" for American work ${ }^{31}$ ), of a wide range of architectural production, from office buildings by Skidmore Owings and Merrill, to retail fit-outs, warehouse and factory designs, and, of course, domestic architecture - frequently featuring houses by Breuer, Drake, Rudolph, and especially the evocatively photographed houses of Neutra.

Thus, at the level of the everyday influence on solving design problems, the US journals, along with $A J$, were of particular significance as workplace journals, while $A R$ provided the requisite stimulation at the intellectual level.

${ }^{30}$ Beard J A Beard oral history project 2.01/01:10:04. ${ }^{31}$ Toomath 5 February 2008 2/0:53:18.
However, neither of these findings presents a satisfactory answer to Hoeta's original question regarding the sources of the influence of Modern architecture, primarily because the question isn't specific enough. It could be argued that the US journals provided more influence via the evocatively photographed Modernist works, given that they were at hand in the office, than the type of knowledge that was drawn from the pages of $A R$ (which admittedly might have operated at a similarly visual level in addition to the esotericism of its text). Furthermore, it is not even conclusive that Modernist ideals were convincingly disseminated by $A R$, given other, albeit related, propagandistic activities undertaken through that journal.

So, this leaves us at the position of being unable to answer the question. However, through challenging the accepted response to the question (but not necessarily overturning it - that point remains inconclusive), there has been, at the very least, a reasonably strong case made for broadening the accepted response (insofar as journals are concerned) to include the US journals $(A F, A R e c$, and $P P)$ as important sources, through visual reference, of Modernist influence in postwar New Zealand architecture - as Toomath quipped, 
"architects tend not to read text anyway." 32

The other finding produced from this research, which is possibly of more importance in relation to my own work, is that re-examining the evidence that underlies one of the historiographic "truths" that have now become embedded in our architectural history narratives, as has been attempted in the writing of this paper, provides the opportunity for significant revision to occur. And while this paper has not necessarily had that outcome (and I do not pretend otherwise - the previous interpretations of the interview can hardly be considered as the historiographic crimes of the century), I believe that it is instructive nevertheless even if it is only concerned with developing a personal manner of "doing history" within the contemporary situation.

The Pers. Comm. in NZ architectural historiography

But in the case of the Hoeta interview, it also raises an issue that is pertinent to the doing of postwar architectural history in this country the accessibility of the key protagonists. An historian can expect to enter an enlightening

${ }^{32}$ Toomath 5 February 2008 2/0:47:00. and intriguing conversation with the relevant architect by simply picking up a telephone and dialing the appropriate number. This inevitably leads to a lazy history method, which might or might not seek corroboration in verifiable evidence, but almost certainly will not address issues of memory and artifice that are core to the proper interpretation of data gathered in the form of oral history - and that is, after all, what is being carried out. Worse than that however, in terms of data reliability, is the fact that the pers. comm. rarely leaves any trace of the primary data - the original "interview" - behind for subsequent researchers to examine, beyond the actual article or paper in which an interpretation of the findings are published. This makes much - but certainly not all - of what constitutes New Zealand's postwar architectural history, of unverifiable authority.

If this conclusion seems overly critical (and I do not exclude my own work from this), perhaps it should be. That the Hoeta interview was recorded, and has been made publicly available is an absolute rarity, and it is only because of this "generosity" that the suspect information could be identified, challenged, and added to. Had the conversation gone unrecorded, that half- answer would have remained the authorized response in perpetuity.

Although the broader "truth" of the significance of US journals is hardly earthshattering, and doesn't necessarily contradict the preeminence of the $A R$, it is nonetheless an important fact to document. And while it is true that the representativeness of these findings can be challenged, insofar as each of the respondents that I interviewed had obvious affinities with architecture in the US (given that they all studied there at postgraduate level) - even this latter phenomenon supports the existence of a more complex situation, which has only been skirted around within existing narratives ${ }^{33}$ : that architecture of the immediate postwar period in this country is less grounded in the colonial gaze toward "home," than in a more inclusive survey of global developments within the discipline.

${ }^{33}$ See Clark \& Walker Looking for the Local pp 54-55, and Jenkins At Home pp 121-126. 


\section{REFERENCES}

Alington, Bill WH Alington oral history project Michael Dudding (interviewer) Wellington: Oral History Centre, Alexander Turnbull Library, 2008.

Alington, Bill Personal communication, interview, 23 January 2008.

Alington, Bill, Jim Beard, George Porter, Bill Toomath, \& Tony Treadwell Interviews with New Zealand Architects, interviewed by Philippa Hoeta, 15 December, 1994. Wellington: Victoria University of Wellington Library: Cass. 2.

Beard, Jim J A Beard oral history project Michael Dudding (interviewer) (unpublished oral history) Wellington: Victoria University of Wellington, 2008.

Clark, Justine, and Paul Walker Looking for the local: architecture and the New Zealand Modern Wellington: Victoria University Press, 2000.

Conway, Martin A "Sensory-perceptual episodic memory and its context: autobiographical memory" Philosophical Transactions of the Royal Society B: Biological Sciences (September 2001) 356(1413):1375-1384.

Findlay, Michael "Barbarians at the Gate: Expatriate NZ Architecture and the Problem of Ultra Modernism" Regional Responses: Papers and Proceedings of the Eighth Annual Conference of the Society of Architectural Historians of Australia and New Zealand, Christchurch, New Zealand, 6-8 July 1991 Ian Lochhead (ed) Christchurch: SAHANZ, 1991:135-147.

Gatley, Julia "For modern living: Government blocks of flats" ed. John Wilson Zeal and crusade: The Modern Movement in Wellington Christchurch: Te Waihora Press, 1996:53-60.

Gatley, Julia "Privacy and Propaganda: The Politics of the Dixon Street Flats" Interstices: A Journal of Architecture and Related Arts (November 1996) 4:1-11

$<$ http://www.architecture.creative.auckland.ac.nz/architectureshowca se.php?thispage $=\mathrm{i} 4>$.
Hänninen, Tuomo Age-associated memory impairment: A neuropsychological and epidemiological study (Kuopio: Univ. of Kuopio, 1996) $<$ http://www.uku.fi/neuro/39the.htm>.

Lloyd Jenkins, Douglas At Home: A Century of New Zealand Design Auckland: Random House, 2004.

Pevsner, Nikolaus "The return of historicism" Nikolaus Pevsner: Pevsner on Art and Architecture Stephen Games (ed) London: Methuen, 2002:271277.

Shaw, Peter A History of New Zealand Architecture Auckland: Hodder Moa Beckett, 1997.

Toomath, Bill Personal communication, interview, 5 February 2008.

Wheeler, Mark A, Donald T Stuss, \& Endel Tulving "Toward a theory of episodic memory: The frontal lobes and autonoetic consciousness" Psychological Bulletin (May 1997) 121(3):331-354. 